\title{
The carbon footprint of dairy production systems through partial life cycle assessment
}

\author{
C. A. Rotz, ${ }^{* 1}$ F. Montes, ${ }^{*}$ and D. S. Chianese $†$ \\ *USDA/Agricultural Research Service, Pasture Systems and Watershed Management Research Unit, University Park, PA 16802 \\ †ENVIRON International Corporation, Los Angeles, CA 90017
}

\section{ABSTRACT}

Greenhouse gas (GHG) emissions and their potential effect on the environment has become an important national and international issue. Dairy production, along with all other types of animal agriculture, is a recognized source of GHG emissions, but little information exists on the net emissions from dairy farms. Component models for predicting all important sources and sinks of $\mathrm{CH}_{4}, \mathrm{~N}_{2} \mathrm{O}$, and $\mathrm{CO}_{2}$ from primary and secondary sources in dairy production were integrated in a software tool called the Dairy Greenhouse Gas model, or DairyGHG. This tool calculates the carbon footprint of a dairy production system as the net exchange of all GHG in $\mathrm{CO}_{2}$ equivalent units per unit of energy-corrected milk produced. Primary emission sources include enteric fermentation, manure, cropland used in feed production, and the combustion of fuel in machinery used to produce feed and handle manure. Secondary emissions are those occurring during the production of resources used on the farm, which can include fuel, electricity, machinery, fertilizer, pesticides, plastic, and purchased replacement animals. A longterm $\mathrm{C}$ balance is assumed for the production system, which does not account for potential depletion or sequestration of soil carbon. An evaluation of dairy farms of various sizes and production strategies gave carbon footprints of 0.37 to $0.69 \mathrm{~kg}$ of $\mathrm{CO}_{2}$ equivalent units/ $\mathrm{kg}$ of energy-corrected milk, depending upon milk production level and the feeding and manure handling strategies used. In a comparison with previous studies, DairyGHG predicted C footprints similar to those reported when similar assumptions were made for feeding strategy, milk production, allocation method between milk and animal coproducts, and sources of $\mathrm{CO}_{2}$ and secondary emissions. DairyGHG provides a relatively simple tool for evaluating management effects on net GHG emissions and the overall carbon footprint of dairy production systems.

Received February 24, 2009.

Accepted December 2, 2009.

${ }^{1}$ Corresponding author: al.rotz@ars.usda.gov
Key words: greenhouse gas, carbon footprint, farm model, DairyGHG

\section{INTRODUCTION}

Atmospheric concentrations of greenhouse gases (GHG) have steadily increased throughout the twentieth century, and this is thought to be contributing to an increase in the surface temperature of the earth and related changes in global climate (IPCC, 2001). Concern over the increased emission and retention of these gases in the atmosphere is growing both nationally and internationally. As a result, scientists and policymakers have focused on both quantifying and reducing anthropogenic emissions of GHG worldwide.

Agriculture is believed to contribute about $6 \%$ of total GHG emissions in the United States, with about half of this emission from livestock and manure sources (EPA, 2008). Although this contribution represents only a small portion of $\mathrm{CO}_{2}$ emissions, agriculture is reported as the largest emitter of $\mathrm{N}_{2} \mathrm{O}$ and second largest emitter of $\mathrm{CH}_{4}$, accounting for 75 and $30 \%$, respectively, of national total emissions (EPA, 2008). The FAO (2006) reported that, worldwide, agriculture contributed more GHG emissions than the transportation sector, but in the United States, emissions from all of agriculture are about $25 \%$ of those released through the combustion of transportation fuel (EPA, 2008). Although there is still uncertainty in specific numbers, agriculture appears to have a significant role in this international issue. Within agriculture, plant production is generally a net sink for $\mathrm{C}$ in the production of food, feed, and fiber products. In livestock agriculture, though, animals, particularly ruminants, release GHG during feed digestion, with further emissions during the handling of their manure.

Greenhouse gases emitted from dairy farms include $\mathrm{CO}_{2}, \mathrm{CH}_{4}$, and $\mathrm{N}_{2} \mathrm{O}$, with various sources and sinks throughout the farm. Measuring the assimilation and emission of these gases on farms is difficult, relatively inaccurate, and very expensive. Emissions are also dependent upon farm management, so large differences can occur among farms. Various processes affecting emissions interact with each other as well as with the 
climate, soil, and other components, making it difficult to predict their overall effect. Therefore, all individual processes and their interactions must be integrated in a comprehensive whole-farm analysis to determine the net result. Arguably, no field study could feasibly record all of the data needed for a farm-specific evaluation. A report from the NRC (2003) recommended a process-based modeling approach incorporating nutrient mass balance constraints and appropriate component emission factors for estimating gaseous emissions from animal feeding operations.

With the growing concern over GHG emissions, a need has developed for expressing the total emission associated with a product or service. A term that has come to represent this quantification is the $\mathrm{C}$ footprint. This term originated from a methodology known as the ecological footprint (Kitzes et al., 2008). This footprint was defined as the area of biologically productive land needed to produce the resources and assimilate the waste generated using prevailing technology. The term C footprint refers specifically to the biologically productive area required to sequester enough $\mathrm{C}$ to avoid an increase in atmospheric $\mathrm{CO}_{2}$. This was originally calculated as the required area of growing, nonharvested forest land. Today, a more practical definition of $\mathrm{C}$ footprint is the net GHG exchange per unit of product or service. This net emission is best determined through a life cycle assessment that includes all important emission sources and sinks within the production system as well as those associated with the production of resources used in the system.

Our goal was to develop a software tool for estimating individual emissions, the net total GHG emission, and the $\mathrm{C}$ footprint of dairy production systems. Specific objectives were to create an easy-to-use model, apply the model in a comparison of a variety of production systems, and evaluate the model through a sensitivity analysis and a comparison with previous studies.

\section{MODEL DESCRIPTION}

Relationships for predicting all important GHG sources and sinks along with a full $\mathrm{C}$ balance of the production system were integrated in a software tool called the Dairy Greenhouse Gas model, or DairyGHG. The major processes of feed allocation, animal intake and production, and manure production and handling are simulated through time over $15 \mathrm{yr}$ of weather to estimate both daily and long-term annual emissions. This software provides a comprehensive yet easy-to-use tool for estimating the emissions and $\mathrm{C}$ footprint of a wide range of dairy production systems. DairyGHG is available for download from the Internet (http://www.ars. usda.gov/Main/docs.htm?docid=17355). Weather files are provided with historical data from 1991 to 2005 for each state in the United States. The software includes an integrated help system and reference manual with detailed documentation of the model.

A partial life cycle assessment (cradle to farm gate) is used to integrate the most appropriate published relationships and emission factors for all important primary and secondary GHG exchanges with the environment. Primary emissions are those emitted from the farm or production system during the actual production process. Secondary emissions are those that occur during the manufacture or production of resources used in the production system. By totaling the net of all annual emissions from both primary and secondary sources and dividing by annual ECM production, a C footprint is determined.

A dairy production system generally represents the dairy farm, but the system boundaries are beyond that of the physical farm (Figure 1). The production system includes the production of all feeds used to maintain the herd. Therefore, emissions during the production of all feed crops are included whether those feeds are produced on the same farm with the animals or they are purchased from another farm. All manure nutrients are assumed to be used in feed-crop production unless a portion or all of the manure is designated as exported from the production system. This approach provides a comprehensive evaluation of the full milk production system that looks beyond specific farm boundaries.

The important GHG in dairy production $\left(\mathrm{CO}_{2}, \mathrm{CH}_{4}\right.$, and $\mathrm{N}_{2} \mathrm{O}$ ) have different potentials for trapping heat in the atmosphere. To standardize emissions, the global warming potential equivalence index has been established (IPCC, 2001). In our model, total GHG emissions are determined in $\mathrm{CO}_{2}$ equivalent $\left(\mathbf{C O}_{2} \mathbf{e}\right)$ units using global warming potential conversions of $25 \mathrm{~kg}$ of $\mathrm{CO}_{2} \mathrm{e} / \mathrm{kg}$ of $\mathrm{CH}_{4}$ and $298 \mathrm{~kg}$ of $\mathrm{CO}_{2} \mathrm{e} / \mathrm{kg}$ of $\mathrm{N}_{2} \mathrm{O}$ (IPCC, 2007).

\section{Primary Sources}

Primary sources of GHG emissions include the net emission of $\mathrm{CO}_{2}$ plus all emissions of $\mathrm{CH}_{4}$ and $\mathrm{N}_{2} \mathrm{O}$ during the production of feeds, maintenance of animals, and handling of manure. For the more important sources of animal and manure storage emissions, process-level simulation is used. For other sources, simpler relationships and emission factors are used.

Carbon Dioxide. Multiple processes assimilate and emit $\mathrm{CO}_{2}$ from dairy farms. Croplands assimilate $\mathrm{CO}_{2}$ from the atmosphere through photosynthetic fixation during crop growth and emit $\mathrm{CO}_{2}$ through plant and soil respiration and manure decomposition. Typically, over a full year, croplands are a net sink; that is, plants 


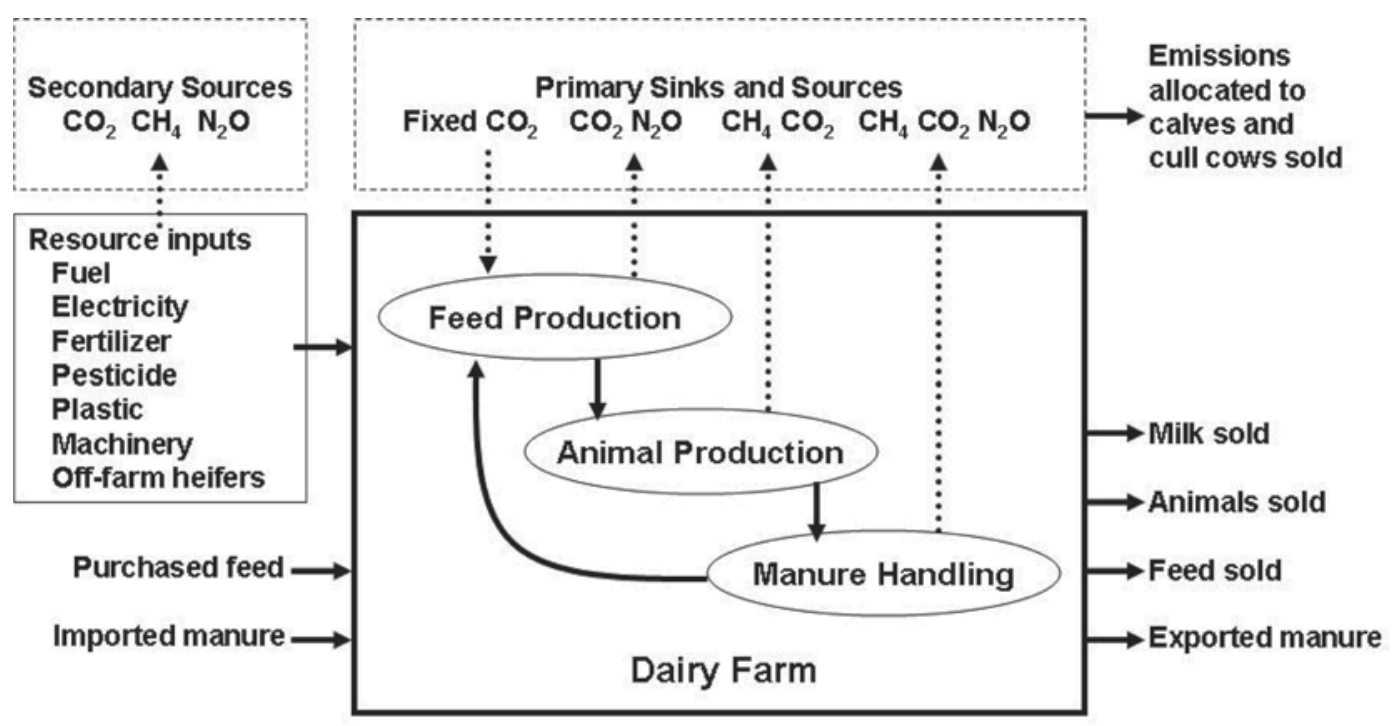

Figure 1. Primary and secondary emission sources and sinks for a partial life cycle assessment of the carbon footprint of dairy production systems.

assimilate more $\mathrm{CO}_{2}$ in plant biomass than is emitted (Chianese et al., 2009a). A major source of $\mathrm{CO}_{2}$ on dairy farms is animal respiration, followed by less significant emissions from manure storages and barn floors.

A relatively simple but robust approach is used to predict net $\mathrm{CO}_{2}$ emission from feed production. The long-term $\mathrm{C}$ balance for the cropland producing feeds is assumed to be zero. Therefore, the sum of all $\mathrm{C}$ leaving the cropping system in feed and emissions is equal to the net assimilated during crop growth plus any other $\mathrm{C}$ entering the system. The major source of nonphotosynthetically fixed $\mathrm{C}$ is land-applied manure.

A C balance is determined considering all flows in and out of cropland during the production of the feeds provided to the herd. By enforcing a long-term balance, the net difference between the $\mathrm{C}$ fixed during crop growth and that emitted through plant and soil respiration must equal the $\mathrm{C}$ removed in harvested feed minus that applied to the cropland in manure. Carbon applied in manure is that excreted by the animals plus the $\mathrm{C}$ in any manure imported to the farm minus all $\mathrm{C}$ lost during manure handling and that in manure exported from the production system. Therefore, the net exchange of $\mathrm{C}$ in feed production is

$\mathrm{C}_{\text {net }}=\mathrm{C}_{\text {feed }}-\left(\mathrm{C}_{\mathrm{exc}}-\mathrm{C}_{\mathrm{CH} 4}-\mathrm{C}_{\mathrm{CO} 2}-\mathrm{C}_{\mathrm{exp}}+\mathrm{C}_{\mathrm{imp}}\right),[1]$

where $\mathrm{C}_{\text {net }}$ is the net $\mathrm{C}$ assimilated in feed production $(\mathrm{kg})$; $\mathrm{C}_{\text {feed }}$ is the $\mathrm{C}$ in feed and bedding material produced minus that in excess feed and bedding sold $(\mathrm{kg})$; $\mathrm{C}_{\text {exc }}$ is the $\mathrm{C}$ in manure excreted by animals on the farm $(\mathrm{kg}) ; \mathrm{C}_{\mathrm{CH} 4}$ is the $\mathrm{C}$ lost as $\mathrm{CH}_{4}$ from the barn floor, dur- ing storage, and following land application $(\mathrm{kg}) ; \mathrm{C}_{\mathrm{CO} 2}$ is the $\mathrm{C}$ lost as $\mathrm{CO}_{2}$ from the barn floor and manure storage $(\mathrm{kg}) ; \mathrm{C}_{\text {exp }}$ is the $\mathrm{C}$ in any manure exported from the production system $(\mathrm{kg})$; and $\mathrm{C}_{\mathrm{imp}}$ is the $\mathrm{C}$ in manure imported to the production system $(\mathrm{kg})$.

The $\mathrm{C}$ content of feeds is set considering their carbohydrate, protein, and fat contents, where the $\mathrm{C}$ contents of these constituents are about 40,53 , and $70 \%$, respectively, based upon their chemical structures (Bailey and Ollis, 1986). Therefore, the C contents of forages and grains, high-protein concentrates, and added fat are about 40,45 , and $70 \%$, respectively. The $\mathrm{C}$ in excreted manure is determined using a $\mathrm{C}$ balance of the herd (i.e., the $\mathrm{C}$ excreted is equal to that consumed in feed minus that emitted by the animals in $\mathrm{CH}_{4}$ and $\mathrm{CO}_{2}$ and that contained in the milk and animal live weight produced). Carbon contents are assigned to milk (12 g of $\mathrm{C} / \mathrm{g}$ of milk $\mathrm{N})$ and animal tissue $(0.23 \mathrm{~g}$ of $\mathrm{C} / \mathrm{g}$ of animal mass) based upon their protein, carbohydrate, and lipid contents (USDA, 2005). Carbon in exported manure is determined as the portion of manure exported times the $\mathrm{C}$ remaining in excreted manure after storage. Imported manure is assumed to have a $\mathrm{C}$ content of $40 \%$ of DM (Griffin et al., 2003).

The net flow of $\mathrm{C}$ in feed production, $\mathrm{C}_{\text {net }}$, represents a net exchange of $\mathrm{CO}_{2}$ with the atmosphere. This exchange of $\mathrm{C}$ is converted to units of $\mathrm{CO}_{2}$ using the ratio of the molecular weight of $\mathrm{CO}_{2}$ to that of $\mathrm{C}(3.67 \mathrm{~kg}$ of $\mathrm{CO}_{2} / \mathrm{kg}$ of $\mathrm{C}$ ).

It is important to note that this approach of forcing a long-term $\mathrm{C}$ balance does not allow for sequestration or depletion of soil C. If major changes in tillage and 
cropping practices are made, soil $\mathrm{C}$ levels can change over several years until the soil again reaches equilibrium (Franzluebbers and Follett, 2005). Although our model does not account for this potential change in soil $\mathrm{C}$, this change can be added or subtracted from the net value determined by Equation 1. To obtain values for C sequestration, the COMET-VR model (http://www. cometvr.colostate.edu/tool/default.asp?action=1) provides a tool for estimating changes in soil $\mathrm{C}$ following changes in production practices.

Carbon dioxide from animal and manure sources is often ignored in GHG accounting (IPCC, 2001, 2007). This respired $\mathrm{CO}_{2}$ is part of the $\mathrm{C}$ cycle that begins with photosynthetic fixation by plants. When the animals consume feed (fixed $\mathrm{C}$ in plant material), some $\mathrm{C}$ is converted back to $\mathrm{CO}_{2}$ through respiration of the animals and microorganisms in their manure. In the overall farm balance, the $\mathrm{CO}_{2}$ released offsets much of the $\mathrm{CO}_{2}$ assimilated in plant material; however, some of the feed intake of $\mathrm{C}$ is released as $\mathrm{CH}_{4}$ and additional $\mathrm{C}$ is in the milk and animal weight produced. To obtain a full accounting and balance of all $\mathrm{C}$ flows up to the farm gate, all sources of $\mathrm{C}$ emission and retention are considered.

Carbon dioxide emission from the herd is predicted as a function of the DMI and BW of each of 6 possible animal groups making up the herd (Chianese et al., 2009b) using a relationship developed by Kirchgessner et al. (1991). The 6 animal groups are young stock under 1 yr old, heifers over 1 yr old, 3 groups of lactating cows, and nonlactating cows (Rotz et al., 1999). Important animal and herd characteristics such as milk production and fat concentration, breed, size, animal numbers, and the annual replacement rate of the lactating animals are defined by the model user.

Animal feed intake, performance, and manure production are modeled using the herd component of the Integrated Farm System Model (Rotz et al., 2009). Rations for a representative animal of each group are formulated using available feeds to meet 4 requirements for roughage, energy, minimum RDP, and minimum RUP (Rotz et al., 1999). Energy, protein, and mineral requirements for each animal group are determined using relationships from the Cornell Net Carbohydrate and Protein System, level 1 (Fox et al., 2004). Diets are formulated and animal production is predicted using a linear program that simultaneously solves 5 constraint equations to maximize herd milk production with minimum cost rations (Rotz et al., 1999). The constraints include a limit on ruminal fill and constraints for each of the 4 requirements.

Floors of housing facilities are a small source of $\mathrm{CO}_{2}$ emission through the decomposition of $\mathrm{OM}$ in manure.
An empirical equation is used to relate $\mathrm{CO}_{2}$ emission to the air temperature and manure surface area in the facility (Chianese et al., 2009b). This same relationship is used for free stall, tie stall, bedded pack, and dry lot facilities.

Compared with other farm sources, manure storages also emit relatively low amounts of $\mathrm{CO}_{2}$. The few data available for this source were used to derive a constant emission factor of $0.04 \mathrm{~kg}$ of $\mathrm{CO}_{2} / \mathrm{d}$ per cubic meter of manure in the storage (Chianese et al., 2009b). This average emission rate is applicable to uncovered storages. Covers are sometimes used, but no data were available documenting the effect of covers on $\mathrm{CO}_{2}$ emission. To model this effect, a cover was assumed to reduce $\mathrm{CO}_{2}$ emission by a similar proportion as found for the more important gas of ammonia (80\%; Rotz, 2004). Therefore, to simulate $\mathrm{CO}_{2}$ emission from a covered storage, the emission rate is reduced to $0.008 \mathrm{~kg}$ of $\mathrm{CO}_{2} / \mathrm{m}^{3}$ per day. To represent a sealed storage where biogas is burned, the loss of $\mathrm{CO}_{2}$ is reduced to that contained in the biogas (40\% of total gas) plus that created through the combustion of $\mathrm{CH}_{4}$ (described below).

During the operation of tractors and other enginepowered equipment, $\mathrm{C}$ in fuel is transformed to $\mathrm{CO}_{2}$ and released in engine exhaust. The conversion factor used is $2.637 \mathrm{~kg}$ of $\mathrm{CO}_{2} / \mathrm{L}$ of diesel fuel (Wang, 2007). Fuel consumed in the production system is estimated using fuel use factors. These factors represent a typical or average amount of fuel used to produce and deliver a unit of feed to the herd or remove a unit of manure. Fuel use factors were determined with the Integrated Farm System Model (Rotz et al., 2009). This farm model simulates feed production and manure handling over many years of weather. By simulating various feed production systems, average amounts of fuel use per unit of feed produced and fed were determined for each of the major feeds used in dairy production (Table 1). With the same approach, a factor for manure handling was determined as $0.6 \mathrm{~L} /$ tonne of manure removed from the barn. By summing the products of the fuel use factors and the amount of each feed used or the amount of manure handled, an estimate of total fuel use is obtained. Fuel use is multiplied by the conversion factor to obtain engine $\mathrm{CO}_{2}$ emissions.

Methane. The majority of $\mathrm{CH}_{4}$ is created through enteric fermentation, followed by emissions from manure storages with minor emissions from manure deposited by animals inside barns or on pasture (EIA, 2006; Chianese et al., 2009c). Most field studies report croplands as a negligible source, or very small sink, of $\mathrm{CH}_{4}$ over full production years (Chianese et al., 2009a). However, field-applied manure can result in significant emissions for a few days after application. In our model, 
Table 1. Use factors for major resource inputs in feed production

\begin{tabular}{|c|c|c|c|c|}
\hline Feed type & $\begin{array}{c}\text { Fuel use }{ }^{1} \\
\text { (L/t DM of feed) }\end{array}$ & $\begin{array}{c}\text { Machine use }{ }^{2} \\
(\mathrm{~kg} / \mathrm{t} \mathrm{DM} \text { of feed })\end{array}$ & $\begin{array}{c}\text { Pesticide use }{ }^{3} \\
\text { (kg of ai/t DM of feed) }\end{array}$ & $\begin{array}{c}\text { Seed use } \\
(\mathrm{kg} / \mathrm{t} \mathrm{DM} \text { of feed })\end{array}$ \\
\hline Grazed forage & 0.0 & 0.0 & 0.05 & 0.9 \\
\hline Alfalfa or grass silage & 25.0 & 5.5 & 0.10 & 0.9 \\
\hline Alfalfa or grass hay & 17.0 & 3.0 & 0.10 & 0.9 \\
\hline Corn silage & 19.0 & 5.5 & 0.30 & 1.7 \\
\hline High-moisture corn & 15.0 & 3.0 & 0.67 & 4.0 \\
\hline Corn grain & 12.0 & 1.5 & 0.67 & 4.0 \\
\hline Protein supplement feed & 10.0 & 2.0 & 0.00 & 0.0 \\
\hline Fat additive & 10.0 & 2.0 & 0.00 & 0.0 \\
\hline
\end{tabular}

the net exchange of $\mathrm{CH}_{4}$ from cropland is neglected except for the emission immediately following manure application.

Ruminant animals produce $\mathrm{CH}_{4}$ through enteric fermentation where this $\mathrm{CH}_{4}$ is released by eructation and respiration. The amount of $\mathrm{CH}_{4}$ produced is influenced by various factors including animal type and size, digestibility of the feed, and the intakes of DM, total carbohydrates, and digestible carbohydrates (Wilkerson et al., 1995; Monteny et al., 2001).

A process model is used to predict this emission source. The model is based on dietary composition and is capable of accounting for management practices that alter the animal's intake and diet. Enteric emission is a function of the metabolizable energy intake and the ratio of the starch content of the diet over the $\mathrm{ADF}$ content using the nonlinear model developed by Mills et al. (2003) as implemented by Chianese et al. (2009c). Daily $\mathrm{CH}_{4}$ emission is predicted for each of the 6 possible animal groups in the herd based upon their diet as determined by the herd component of the model (Rotz et al., 1999). This component determines the energy and fiber contents of the diet, total DMI, and the amount of each feed consumed. The model predicts an observed trend of increased $\mathrm{CH}_{4}$ emission with high-fiber diets and decreased emission with high-starch diets.

Manure on housing floors is also a small source of $\mathrm{CH}_{4}$ where the emission depends upon the manure handling procedures used. For manure deposited on the floor of free stall and tie stall barns, an empirical relationship is used to predict the emission as a function of air temperature and manure surface area in the facility (Chianese et al., 2009c). When manure accumulates in a bedded pack, $\mathrm{CH}_{4}$ emissions are increased. For this management option, an adaptation of the tier 2 approach of the IPCC (2006) is used. Emission on a given day is determined as a function of the total volatile solids (VS) excreted on the floor and a $\mathrm{CH}_{4}$ conversion factor (MCF):

$$
\mathrm{ECH} 4=\mathrm{VS} \times \mathrm{B}_{\mathrm{o}} \times 0.67 \times \mathrm{MCF} / 100,
$$

where ECH4 is the daily $\mathrm{CH}_{4}$ emission $\left(\mathrm{kg}\right.$ of $\left.\mathrm{CH}_{4} / \mathrm{d}\right)$; $\mathrm{B}_{\mathrm{o}}$ is the maximum $\mathrm{CH}_{4}$ producing capacity for dairy manure $\left(0.24 \mathrm{~m}^{3}\right.$ of $\mathrm{CH}_{4} / \mathrm{kg}$ of $\left.\mathrm{VS}\right) ; 0.67$ is a conversion factor of cubic meters of $\mathrm{CH}_{4}$ to kilograms of $\mathrm{CH}_{4}$; and $\mathrm{MCF}$ is the $\mathrm{CH}_{4}$ conversion factor for the manure management system (\%). For a bedded pack, MCF is modeled as an exponential function of average temperature through a regression of the data provided by the IPCC (2006):

$$
\mathrm{MCF}=7.11 \mathrm{e}^{0.00884\left(\mathrm{~T}_{\mathrm{b}}\right)}
$$

where $\mathrm{T}_{\mathrm{b}}$ is average daily barn temperature $\left({ }^{\circ} \mathrm{C}\right)$ and MCF is limited to a maximum value of $80 \%$.

In warm, dry climates, animals are often housed in open, nonvegetated drylots. Manure typically accumulates on the soil surface for weeks or months before being removed. To predict the emission from this surface, the tier 2 approach of IPCC (2006) is again used (Equation 2). Based upon the IPCC (2006) data for a drylot facility, MCF is modeled as a linear relationship with ambient temperature:

$$
\mathrm{MCF}=0.0625 \mathrm{~T}_{\mathrm{a}}+0.25,
$$

where $T_{a}$ is average daily ambient temperature $\left({ }^{\circ} \mathrm{C}\right)$ and $\mathrm{MCF}$ is limited to a minimum value of 0 . In systems that combine free stall and drylot housing, the assumption is made that half of the manure is deposited in free stall alleys, with the remainder deposited on the drylot. The total emission is then the sum of the 2 sources. 
To predict emissions from slurry and liquid manure storages, a model developed by Sommer et al. (2004) is used. The production and emission of $\mathrm{CH}_{4}$ is simulated based upon the degradation of VS as affected by temperature and storage time (Chianese et al., 2009c). The total and degradable VS entering storage are a function of the amount of manure excreted, the solids content, and other characteristics of the manure. Total VS in the manure storage at any point in time is the difference between that loaded into the storage and that lost from the storage up to that point. The amount of manure in the storage is the accumulation of that produced by the herd when in confined facilities, with daily manure excretion determined in the animal component (Rotz et al., 1999). The temperature of the manure in storage on a given simulated day is estimated as the average ambient air temperature over the previous $10 \mathrm{~d}$.

This predicted storage emission is for an uncovered, bottom-loaded storage of slurry manure $(7-12 \% \mathrm{DM})$ where a crust forms on the surface. For a top-loaded tank or with manure containing less DM, this emission rate is increased $40 \%$ (IPCC, 2006). With a nonsealed cover, the emission rate is reduced by $80 \%$, similar to that discussed above for $\mathrm{CO}_{2}$. A more tightly sealed cover or enclosed storage can be used where the biogas produced is burned to convert the emitted $\mathrm{CH}_{4}$ to $\mathrm{CO}_{2}$. To simulate this storage treatment, the emission of $\mathrm{CH}_{4}$ is reduced by $99 \%$ (EPA, 1999). The subsequent flaring of the captured $\mathrm{CH}_{4}$ releases $\mathrm{CO}_{2}$. This additional $\mathrm{CO}_{2}$ created through combustion is determined by the ratio of the molecular weights of $\mathrm{CO}_{2}$ and $\mathrm{CH}_{4}$ (i.e., 2.75 times the $\mathrm{CH}_{4}$ produced in the storage).

Semisolid (8-15\% DM) and solid ( $>15 \%$ DM) manure can be stored in stacks. Methane emission from this type of storage is modeled using the tier 2 approach of the IPCC (2006). Daily emissions are determined using Equation 2, with VS defined as the total VS placed into the storage each day. Using the recommended data of the IPCC (2006), MCF is modeled as a function of the temperature of the stored manure:

$$
\mathrm{MCF}=0.201 \mathrm{~T}_{\mathrm{m}}-0.29,
$$

where MCF is limited to a minimum value of $0 \%$ and $\mathrm{T}_{\mathrm{m}}$ is stored manure temperature $\left({ }^{\circ} \mathrm{C}\right)$. Again, manure temperature is the average ambient temperature over the previous $10 \mathrm{~d}$.

Field-applied slurry is a source of $\mathrm{CH}_{4}$ for several days after application, emitting 40 to $90 \mathrm{~g}$ of $\mathrm{CH}_{4} / \mathrm{ha}$ per day (Sommer et al., 1996; Sherlock et al., 2002). Emissions rapidly decrease within a few days, and the soils return to a neutral source of $\mathrm{CH}_{4}$. The emission from freshly applied manure is modeled as a function of the VFA content of the manure, where this content declines exponentially through time (Chianese et al., 2009c). This emission occurs until the remaining VFA is insignificant or until the manure is incorporated into the soil by tillage. If manure is directly injected into the soil, this emission is eliminated.

On farms that incorporate grazing for at least a portion of the year, freshly excreted feces and urine are directly deposited on pastures. Studies have shown that feces is a small source of $\mathrm{CH}_{4}$, and the emission from urine is not significantly different from background soil emissions (e.g., Jarvis et al., 1995; Yamulki et al., 1999). From the limited available data, an average emission factor of $0.76 \mathrm{~g}$ of $\mathrm{CH}_{4} / \mathrm{kg}$ of feces DM is used (Chianese et al., 2009c). Therefore, for grazing systems, the daily emission of $\mathrm{CH}_{4}$ is the product of this emission factor and the daily amount of feces deposited by grazing animals. The amount deposited on pasture is proportional to the amount of time the animals are on pasture each day.

Nitrous Oxide. The major sources of $\mathrm{N}_{2} \mathrm{O}$ are denitrification and nitrification processes occurring in the soil where crops are grown to feed the herd. These processes can also occur in the crust on the surface of a slurry manure storage, in stacked manure, in bedded pack manure on barn floors, and on manure-laden drylot surfaces.

To simplify this software tool, soil processes are not simulated. Therefore, a relatively simple emission factor approach had to be used to estimate $\mathrm{N}_{2} \mathrm{O}$ emissions in the production of feeds. Based upon the recommendation of the IPCC (2006), the $\mathrm{N}_{2} \mathrm{O}-\mathrm{N}$ emission from cropland was assumed to be $1 \%$ of the $\mathrm{N}$ applied and that from grazed pastureland is $2 \%$ of applied N. Because crop production is not simulated, $\mathrm{N}$ applied is set as $40 \%$ greater than that removed in harvested feed. This approach assumes relatively efficient use of $\mathrm{N}$ fertilizer in producing the feed crops. The overapplication of $40 \%$ allows for the loss of $\mathrm{N}$ in crop production that naturally occurs when $\mathrm{N}$ is applied at a recommended rate to meet nutrient removal. To predict $\mathrm{N}$ application, the total $\mathrm{N}$ in the feed consumed by the herd is determined as the sum of the DM for each feed consumed times the protein content divided by 6.25 . This $\mathrm{N}$ is increased by $40 \%$ and multiplied by the appropriate emission factor and an $\mathrm{N}$ to $\mathrm{N}_{2} \mathrm{O}$ conversion factor of 1.57 .

This approach was evaluated by comparing predicted emissions from this simple model to those predicted by a more complex process-based approach in the Integrated Farm System Model (Rotz et al., 2009). In general, average annual values predicted by the 2 ap- 
proaches were similar even though this simple approach did not account for differences in soil type and climate conditions.

Manure removed daily from the floors of free stall and tie stall barns is a negligible source of $\mathrm{N}_{2} \mathrm{O}$ emission (Chianese et al., 2009d). For bedded pack and drylot surfaces where manure remains for longer periods, emissions are greater. Using the IPCC (2006) tier 2 approach, emission factors of 0.01 and $0.02 \mathrm{~kg}$ of $\mathrm{N}_{2} \mathrm{O}-\mathrm{N} /$ $\mathrm{kg}$ of $\mathrm{N}$ excreted are used for bedded pack and drylot facilities, respectively. The total $\mathrm{N}$ excreted in each facility is multiplied by the appropriate emission factor and the $\mathrm{N}$ to $\mathrm{N}_{2} \mathrm{O}$ conversion factor (1.57) to obtain $\mathrm{N}_{2} \mathrm{O}$ emission.

Nitrous oxide emission from slurry or liquid manure is a function of the exposed surface area of the manure storage and the presence of a crust on the surface. For an open slurry storage tank with a crust, an average emission rate of $0.8 \mathrm{~g}$ of $\mathrm{N}_{2} \mathrm{O} / \mathrm{m}^{2}$ per day determined by Olesen et al. (2006) is used to predict $\mathrm{N}_{2} \mathrm{O}$ emissions. When a natural crust does not form on the stored slurry, no $\mathrm{N}_{2} \mathrm{O}$ is formed and emitted (Chianese et al., 2009a). This occurs if the manure DM content is less than $8 \%$, manure is loaded daily onto the top surface of the storage, or an enclosed tank is used. Therefore, when any of these manure handling options are selected, the emission rate is zero. For stacked manure with a greater DM content, an emission factor of $0.005 \mathrm{~kg}$ of $\mathrm{N}_{2} \mathrm{O}-\mathrm{N} /$ $\mathrm{kg}$ of $\mathrm{N}$ excreted is used (IPCC, 2006).

\section{Secondary Sources}

Secondary sources included in the model are the production of fuel, electricity, machinery, fertilizer, pesticide, and plastic used in the production of feeds, maintenance of animals, and handling of manure. Also included are the emissions during the production of any replacement animals not raised on the farm. Secondary emissions are all expressed in annual values of $\mathrm{CO}_{2} \mathrm{e}$ units. Most of these emissions are in the form of $\mathrm{CO}_{2}$, but where appropriate, $\mathrm{CH}_{4}$ and $\mathrm{N}_{2} \mathrm{O}$ emissions are converted to $\mathrm{CO}_{2} \mathrm{e}$ units and included in these emission factors.

Emissions during the production of fuel and electricity are set using emission factors from Wang (2007). These factors are $0.374 \mathrm{~kg}$ of $\mathrm{CO}_{2} \mathrm{e} / \mathrm{L}$ of fuel and 0.73 $\mathrm{kg}$ of $\mathrm{CO}_{2} \mathrm{e} / \mathrm{kWh}$ of electricity used. Fuel use is estimated as described above. Electricity is the total of that used for milking-related activities, lighting, and ventilation. That required for milking activities is estimated as $0.06 \mathrm{kWh} / \mathrm{kg}$ of milk produced (Ludington and Johnson, 2003). Annual electricity use for lighting is set as $0 \mathrm{kWh}$ for a drylot and $120 \mathrm{kWh}$ per cow for all other facilities; that used in ventilation is 0,75 , and 175
$\mathrm{kWh} /$ cow for drylots, naturally ventilated barns, and mechanically ventilated barns, respectively (Ludington and Johnson, 2003). When drylot and free stalls are combined, electrical use is the average of the 2 facilities. When grazing is used, electrical use for lighting and ventilation are set proportional to the time animals spend in the barn.

Secondary emissions associated with machinery include both the initial manufacture and the repairs required to maintain the equipment. These emissions are primarily caused by the energy used to extract and process steel, which accounts for the majority of the mass of agricultural machines (Doering, 1980; Bowers, 1992; Fluck, 1992). Based on this premise, an average GHG emission factor for the production of machinery is set at $3.54 \mathrm{~kg}$ of $\mathrm{CO}_{2} \mathrm{e} / \mathrm{kg}$ of machinery mass. This emission factor was established based upon available sources of information on embodied energy or emissions in the manufacture of agricultural machinery (Schroll, 1994; Lee et al., 2000; Graboski, 2002; Farrell et al., 2006; Wu et al., 2006; Wang, 2007).

Machinery use factors were derived for the production of each major type of feed using the Integrated Farm System Model (Rotz et al., 2009). Various production systems were simulated over a wide range of farm sizes. From model output, the total mass of machinery needed to produce each feed was totaled, and this total was increased in proportion to the repairs used over the life of each machine. This total mass of machinery was then divided by the total feed produced over the life of the machine to obtain the machine use factor associated with each feed ( $\mathrm{kg}$ of machinery $/ \mathrm{kg}$ of feed). Machinery use factors for a relatively small (100 cow) farm are listed in Table 1. Using the same procedure, a machine use factor of $0.17 \mathrm{~kg} / \mathrm{kg}$ of manure was obtained for manure handling on this small farm.

On larger farms, machines are generally used more efficiently, providing some reduction in the machinery required per unit of feed produced. From further simulation data of the Integrated Farm System Model, an adjustment for farm size was determined as

$$
\mathrm{ADJ}=1.06-0.0006 \mathrm{COWS},
$$

where ADJ is a scaling factor for herd size and COWS is the number of cows in the dairy herd. Therefore, as herd size increases, the machinery use factor is reduced by this scale adjustment. A lower limit on this scaling factor is set at 0.46 so that herd sizes greater than 1,000 cows provide no further improvement in machinery efficiency. Machinery use factors are multiplied by the associated use and summed over all feed used and manure handled to give a total portion of the machinery mass apportioned to each simulated year. This total, 
multiplied by the emission factor of $3.54 \mathrm{~kg}$ of $\mathrm{CO}_{2} \mathrm{e} / \mathrm{kg}$ of machinery, gives an annual value for this secondary emission source.

Emission factors for the manufacture of fertilizer were obtained from Wang (2007). Factors for nitrogen, phosphate, and potash are $3.307,1.026$, and $0.867 \mathrm{~kg}$ of $\mathrm{CO}_{2} \mathrm{e} / \mathrm{kg}$ of each respective fertilizer used in the production of feed. Fertilizer use is estimated as a function of the nutrients removed in the feed. As noted above, $\mathrm{N}$ use is set at $140 \%$ of the $\mathrm{N}$ contained in feeds, and phosphate and potash use are set at $110 \%$ of that contained in each feed to allow for typical nutrient losses in crop production. With these assumptions, a total requirement of each fertilizer is estimated. This total is reduced to account for manure nutrients returned to the cropland producing the feed. The quantities of each of the 3 major manure nutrients are available from the manure production and handling components of the model (Rotz et al., 1999). This approach represents efficient use of manure and fertilizer nutrients. For manure not returned to cropland producing feed, the model user can specify the portion of the manure exported from the production system. The $\mathrm{C}$ and other nutrients for this manure are removed and the balance is satisfied through inorganic fertilizers, or imported manure, or both.

Emissions in the manufacture of pesticides are generally small. Pesticide use is estimated using factors set considering typical requirements for producing each feed (Table 1). The total pesticide use is this factor times the amount of each feed used summed over all feeds. An average emission factor of $22 \mathrm{~kg}$ of $\mathrm{CO}_{2} \mathrm{e} /$ $\mathrm{kg}$ of pesticide active ingredient is used based upon Wang (2007) and other sources (Pimentel, 1980; Fluck, 1992; Bath et al., 1994; Dalgaard et al., 2001; West and Marland, 2002; Patzek, 2004).

Emissions in the production of seed are modeled similar to that of pesticides. Again, this source is very small. Seed use factors were derived from typical seeding rates and yields of each crop (Table 1). Seed use is then summed over all feeds fed. An emission is determined using an emission factor of $0.3 \mathrm{~kg}$ of $\mathrm{CO}_{2} \mathrm{e} / \mathrm{kg}$ of seed. This factor was estimated considering all emissions in producing the seed minus the $\mathrm{CO}_{2}$ assimilated in the seed (Borjesson, 1996; Nagy, 1999; Graboski, 2002; West and Marland, 2002; Patzek, 2004; Schmer et al., 2008). This value will vary among feed crops, but because of the lack of available information and the low importance of this source, this average is used.

Plastic is often used in silage production for bags, silo covers, and bale wrap. Plastic use factors for tower silos, bunker silos, silage bags, and bale silage are 0.0 , $0.3,1.8$, and $3.6 \mathrm{~kg} / \mathrm{t} \mathrm{DM}$ of stored feed for each storage type, respectively (Savoie and Jofriet, 2003). The emission factor for plastic production is set at $2.0 \mathrm{~kg}$ of $\mathrm{CO}_{2} \mathrm{e} / \mathrm{kg}$ of plastic use (IPCC, 2006; Garrain et al., 2007; AMPE, 2008). This emission source is normally small and relatively unimportant compared with other secondary sources.

When heifers are purchased and brought onto the farm, the secondary emissions associated with their production must be included. These emissions vary with the production practices used. To determine an emission factor, DairyGHG was used to determine the emissions for producing heifers over a wide range of farm sizes and feeding strategies. The range found for this secondary source was 8 to $14 \mathrm{~kg}$ of $\mathrm{CO}_{2} \mathrm{e} / \mathrm{kg}$ of BW produced, with the lower values associated with larger farms or grazing production systems. An average emission factor of $11 \mathrm{~kg}$ of $\mathrm{CO}_{2} \mathrm{e} / \mathrm{kg}$ of $\mathrm{BW}$ was selected to best represent this source. This secondary emission is determined by multiplying this factor by the total BW of animals purchased to meet the replacement rate of the dairy herd. If all replacements are raised on the farm, this source is eliminated. If extra animals are raised and sold from the farm, secondary emissions are reduced by the weight sold.

\section{Allocation Between Milk and Animal Production}

A remaining issue in dairy production is the allocation of the total emission between the milk and animal coproducts produced on the farm. In our model, the animal coproduct includes extra calves and cull cows sold from the farm. As discussed above, emissions associated with heifers used on the farm are included as determined by the replacement rate of the lactating cows and the heifer mortality rate. Extra calves and cull cows are sold for meat and other products, so a portion of the emissions from the farm should be associated with these products.

Cederberg and Stadig (2003) discuss 4 options for allocating emissions between milk and beef production in a life cycle assessment: no allocation, economic allocation, cause - effect biological allocation, and system expansion. With no allocation, all emissions are attributed to milk production with no allocation toward the animals sold. For an economic allocation, whole farm emissions are allocated between the 2 products based upon the annual income received from each. Several criteria can be used as a basis for a biological allocation. A suggested approach is to allocate based upon the energy required to produce or the energy available from each product. The final option of system expansion avoids allocation by expanding the system to include the alternative method of producing the coproduct. In this case, the alternative is to produce animals in a beef production system. 
After considering the 4 options, the economic allocation procedure was selected for our model. The noallocation option creates an unfair bias against milk production by associating all emissions to this product. Even though Cederberg and Stadig (2003) recommend the use of system expansion, this approach creates an unfair bias in favor of milk production. Crediting the same emissions to the animals produced on the farm as those produced in a beef production system essentially removes any allocation for dairy animal production. This means that all emissions associated with growing animals are fully accounted to beef production even though they are a necessary part of milk production. This creates a substantial reduction in the emissions associated with milk production. Both the economic and biological allocation schemes provide more moderate and similar division of the net emissions between the products (Cederberg and Stadig, 2003). The biological approach can be very complex, particularly if the various animal products other than meat are considered. We chose the economic option. Because product prices reflect their value to society, allocation by their economic value provided a practical approach.

To implement the economic option, long-term prices for calves and cull cows were established relative to milk. Calf and cull cow prices per unit of mass were set at 6.5 and 2.8 times that of milk, respectively (PASS, 2008). With these price ratios, the replacement rate of the lactating herd, and animal mortality rates, the fraction of total farm emissions attributed to milk production $\left(\mathrm{F}_{\mathrm{m}}\right)$ was determined as

$$
\begin{aligned}
& \mathrm{F}_{\mathrm{m}}=\mathrm{MILK} /\left(2.8 \times \mathrm{N}_{\text {cow }} \times \mathrm{BW}_{\text {cow }}+6.5 \mathrm{~N}_{\text {calf }}\right. \\
&\left.\times \mathrm{BW}_{\text {calf }}+\mathrm{MILK}\right),
\end{aligned}
$$

where $\mathrm{N}_{\text {cow }}$ and $\mathrm{N}_{\text {calf }}$ are the number of cull cows and calves sold annually from the farm; $\mathrm{BW}_{\text {cow }}$ and $\mathrm{BW}_{\text {calf }}$ are the average BW of the cull cows and calves sold $(\mathrm{kg})$; and MILK is the mass of milk sold annually $(\mathrm{kg})$. This portion varies among production systems, but generally 90 to $94 \%$ of the net farm emissions are allocated to milk production, with the remainder allocated to the production of the calves and cull cows sold.

\section{MODEL APPLICATION}

\section{Comparison of Farm Production Systems}

To illustrate use of the model, a series of simulations was done to compare production strategies for 4 representative farms in central Pennsylvania and 2 in southern California. The first of the simulated Pennsylvania farms was relatively small, with 60 cows plus their replacements. Moderate-sized Holsteins were used, with a mature cow weight of $650 \mathrm{~kg}$. Annual milk production was $8,500 \mathrm{~kg} / \mathrm{cow}$, with $3.5 \%$ fat and $3.1 \%$ protein concentrations. Cows were housed in a tie stall barn, with heifers housed in a bedded pack barn. Manure from the tie stall barn was hauled and applied to fields each day, where the manure was handled in a semisolid form with daily use of $2.5 \mathrm{~kg} /$ cow of straw bedding. All animals were fed high-forage diets, with similar amounts of forage coming from corn silage, alfalfa silage, and alfalfa hay. The annual lactating cow replacement rate was $35 \%$, with calves born randomly throughout the year.

A major emission for this production system was $\mathrm{CH}_{4}$ generated by the animals and the bedded pack manure in the heifer facility (Table 2). Of this total, $76 \%$ came from enteric fermentation. Nitrous oxide emissions were relatively small, but considering their large effect on global warming, these small levels had an effect on overall GHG emissions. About half of the total GHG emission for the production system came from $\mathrm{CO}_{2}$ emitted by the animals and manure in their housing facilities. This emission source was more than offset by the assimilation of $\mathrm{CO}_{2}$ in feed production, so overall the farm was a net sink for $\mathrm{CO}_{2}$. Emissions through the combustion of fuel were relatively small compared with other sources. The total from secondary sources was greater, making up $20 \%$ of the net total of all sources and sinks. This general trend among the various sources and sinks was similar across all production systems (Table 2). The net GHG emission or $\mathrm{C}$ footprint for this production system was $0.69 \mathrm{~kg}$ of $\mathrm{CO}_{2} \mathrm{e} / \mathrm{kg}$ of ECM.

The second production system used the same herd, facilities, and milk production as the first farm. A similar feeding strategy was also used except that during 6 mo of the year, all cows and older heifers were supplemented through rotational grazing of pasture. During this time, these animals received about $65 \%$ of their forage from pasture, so $35 \%$ less hay and silage were produced and fed over the full year. This production system could potentially include a transition of row-crop land to permanent grassland, which would enhance $\mathrm{C}$ sequestration. This potential benefit during the transition period was not included here, but is discussed later.

Methane emission from the farm was reduced $13 \%$, primarily because of reduced use of the bedded pack during the warm summer months. Nitrous oxide emissions increased $33 \%$ with the use of pasture because of greater emissions from the high concentration of $\mathrm{N}$ in urine deposits. Emissions from fuel combustion were reduced $30 \%$ with fewer machinery operations, and secondary emissions were reduced through less use of equipment, fuel, and electricity with grazing. The 
Table 2. Greenhouse gas (GHG) emissions from simulated representative farms illustrating the effects of management and location on the carbon footprint of dairy production systems ${ }^{1}$

\begin{tabular}{|c|c|c|c|c|c|c|}
\hline \multirow[b]{2}{*}{ Emission type and source } & \multicolumn{4}{|c|}{ Pennsylvania farms } & \multicolumn{2}{|c|}{ California farms } \\
\hline & $\begin{array}{l}60 \text { cow } \\
\text { confined }\end{array}$ & $\begin{array}{l}60 \text { cow } \\
\text { grazing }\end{array}$ & $\begin{array}{l}500 \text { cow } \\
\text { confined }\end{array}$ & $\begin{array}{c}2,000 \text { cow } \\
\text { drylot }\end{array}$ & $\begin{array}{l}500 \text { cow } \\
\text { confined }\end{array}$ & $\begin{array}{c}2,000 \text { cow } \\
\text { drylot }\end{array}$ \\
\hline \multicolumn{7}{|l|}{ Methane (kg of $\left.\mathrm{CH}_{4} / \mathrm{cow}\right)$} \\
\hline Animals and housing & 233 & 202 & 145 & 147 & 142 & 143 \\
\hline Manure storage & 0 & 0 & 64 & 22 & 90 & 31 \\
\hline Field-applied manure & 1 & 0 & 0 & 0 & 0 & 0 \\
\hline Manure storage & 0 & 0 & 2 & 1 & 2 & 1 \\
\hline Cropland & 5 & 7 & 4 & 4 & 4 & 4 \\
\hline \multicolumn{7}{|l|}{ Carbon dioxide ( $\mathrm{kg}$ of $\left.\mathrm{CO}_{2} / \mathrm{cow}\right)$} \\
\hline Animals and housing & 6,184 & 5,870 & 6,594 & 6,642 & 6,705 & 6,752 \\
\hline Manure storage & 0 & 0 & 169 & 85 & 163 & 83 \\
\hline Cropland & $-9,074$ & $-8,671$ & $-9,959$ & $-9,820$ & $-10,128$ & $-9,945$ \\
\hline \multicolumn{7}{|l|}{ Total $\mathrm{GHG}^{2}\left(\mathrm{~kg}\right.$ of $\left.\mathrm{CO}_{2} \mathrm{e} / \mathrm{cow}\right)$} \\
\hline Net total & 6,372 & 5,793 & 5,753 & 5,026 & 6,231 & 5,093 \\
\hline Allocated to milk (\%) & 91.7 & 91.7 & 92.1 & 92.1 & 92.1 & 92.1 \\
\hline Carbon footprint ${ }^{3}\left(\mathrm{~kg}\right.$ of $\mathrm{CO}_{2} \mathrm{e} / \mathrm{kg}$ of ECM $)$ & 0.69 & 0.62 & 0.53 & 0.46 & 0.57 & 0.47 \\
\hline
\end{tabular}

${ }^{1} 60$ cow confined $=60$ moderate-sized Holstein cows plus replacement heifers housed in tie stall and bedded pack barns, respectively. Annual milk production is $8,500 \mathrm{~kg} / \mathrm{cow}$. All animals are fed high-forage diets (about 51, 64, and $74 \%$ forage for early, mid, and late lactation groups, respectively) with equal amounts of corn silage, alfalfa silage, and alfalfa hay. Manure from tie stalls is spread daily. 60 cow grazing $=$ same as 60 cow confined except that during 6 mo of the year all cows and older heifers are rotationally grazed on perennial grass pasture. Note that this does not include potential carbon sequestration during the transition from row crop to permanent perennial grassland. 500 cow confined $=500$ large Holstein cows plus replacement heifers housed in free stall barns. The herd has an annual milk production of 10,000 kg/cow fed high-grain diets (about $45 \%$ forage for all lactating groups) with equal amounts of forage from corn and alfalfa silages. Manure is stored and spread in the spring and fall. 2,000 cow drylot $=2,000$ large Holstein cows plus replacement heifers housed in free stall barns with drylots. The annual herd production is 10,000 kg of milk/cow fed high-grain diets (about $45 \%$ forage for all lactating groups) with equal amounts of forage from corn and alfalfa silages. Free stall manure is stored and spread in spring and fall.

${ }^{2} \mathrm{CO}_{2}$ equivalents for methane and nitrous oxide are 25 and 298 , respectively.

${ }^{3} \mathrm{CO}_{2} \mathrm{e}=\mathrm{CO}_{2}$ equivalent. ECM = energy corrected milk with $3.5 \%$ fat and $3.1 \%$ protein concentrations.

net GHG emission and C footprint were both reduced about $9 \%$ compared with the full confinement production strategy used on the first farm (Table 2, column 2 vs. column 1).

As a third production strategy, a larger farm with 500 cows and their replacements was simulated. All animals were housed in free stall barns, sand bedding was used, and manure was accumulated in a lined earthen pit. In the spring and fall, the pit was emptied, with all manure going back to cropland producing feed. A bottomloaded manure storage was used, which allowed a crust to form on the surface. The lactating animals were fed high-grain diets (as modeled by Rotz et al., 1999), with about half of the forage coming from corn silage and the remainder from alfalfa silage. Large-framed Holstein animals were used, with a mature cow weight of $715 \mathrm{~kg}$. Annual milk production was $10,000 \mathrm{~kg} / \mathrm{cow}$, containing $3.5 \%$ fat and $3.1 \%$ protein. The calving strategy and replacement rate were the same as the previous farms.
With the use of free stall barns and more grain in diets, the $\mathrm{CH}_{4}$ emission per cow from the animal and housing sources was reduced by $38 \%$ compared with the smaller confinement farm (Table 2, column 3 vs. column 1). The use of long-term manure storage greatly increased the emissions of all 3 GHG during manure handling. Emissions from fuel combustion and secondary sources also increased slightly with these feeding and manure handling strategies. Overall, the net GHG emission per cow was $10 \%$ less than that of the smaller farm, and with the greater milk production, the $\mathrm{C}$ footprint was reduced by $23 \%$.

A fourth farm simulated in Pennsylvania included 2,000 cows housed in a combined free stall and drylot facility. This is not a common production strategy for this region because of the relatively wet and cold climate; it was simulated, though, to provide a direct comparison with production strategies commonly used in California. All other animal characteristics and man- 
agement options were the same as those described for the 500 cow production system.

Compared with the 500 cow farm, use of the drylot increased $\mathrm{CH}_{4}$ production per cow a small amount but reduced that produced in the manure storage (Table 2, column 4 vs. column 3). Nitrous oxide emission also increased with the use of the drylot, and $\mathrm{CO}_{2}$ emissions were similar between these production systems. Overall, GHG emission per cow and the C footprint were $13 \%$ less than that of the full confinement system with the same milk production and similar feeding strategy.

The 500 and 2,000 cow production systems were then simulated using southern California weather. All other management parameters were held the same as those used in Pennsylvania to determine the effect of climate on GHG emissions. The primary effect of the change in climate was a $41 \%$ increase in $\mathrm{CH}_{4}$ emission from the manure storage. The milder climate of California also had a small effect on the nutrient requirements of the animals (Fox et al., 2004). The resulting effect on feed intake caused small changes in animal $\mathrm{CH}_{4}$ and $\mathrm{CO}_{2}$ emissions, the combustion of fuel used in feed production, and the secondary emissions from resources used in feed production. Overall, the net GHG emission was greater in California. For the 500 cow farm, the $\mathrm{C}$ footprint was $8 \%$ greater, but for the 2,000 cow farm, the footprint was only $2 \%$ greater (Table 2 , columns 5 and 6 vs. columns 3 and 4 ).

\section{Comparison of Management Strategies}

A second series of farm simulations was done to study the effects of individual management changes. The 5 management changes were 1) increased milk production through genetic improvement and improved feed management, 2) increased milk production through genetic improvement, improved feed management, and the use of recombinant bST, 3) increased use of forage in lactating cow diets, 4) production and use of more corn silage and less alfalfa forage, and 5) use of an enclosed manure storage with a flare to burn the biogas produced.

The base farm represented 100 Holstein cows of average frame size (mature cow $=650 \mathrm{~kg}$ of $\mathrm{BW}$ ) plus their replacements housed in naturally ventilated free stall barns in Pennsylvania. A random calving strategy was used where heifers raised on the farm met an annual lactating cow replacement rate of $35 \%$. Manure was stored up to 6 mo in an open tank and applied to cropland in the spring and fall. An annual ECM production of $9,000 \mathrm{~kg} / \mathrm{cow}$ was maintained, with lactating animals fed high-grain diets. Forage was 50\% corn silage, 35\% alfalfa silage, and $15 \%$ hay.
To simulate the benefits of improved animal genetics and feeding management, animals were changed to Holsteins of large frame size (mature cow $=715 \mathrm{~kg}$ of BW). Improved feeding practices were represented by increasing the milk production goal so that production was limited by feed quality (Rotz et al., 1999). With these changes, ECM production was maximized for the given feeding strategy at an annual level of about $10,400 \mathrm{~kg} /$ cow. Feed intake increased to meet the nutrient requirements of the larger, higher producing animals, and this increased $\mathrm{CH}_{4}$ and $\mathrm{CO}_{2}$ emissions. More manure was also produced, which increased manure storage emissions of these 2 gases. With greater feed use, cropland provided a greater sink of $\mathrm{CO}_{2}$, but fuel combustion and secondary emissions both increased. The net GHG emission increased $6 \%$, but the greater ECM production reduced the $\mathrm{C}$ footprint by $8 \%$ (Table 3, column 2 vs. column 1).

For even greater production, recombinant bST was included in the next production strategy. This changed the shape of the lactation curve, allowing the model to predict an additional 10\% increase in annual ECM production. This also increased feed intake, which created further increases in GHG emissions from the animals, manure storage, fuel combustion, and secondary sources. The net GHG emission increased another $1 \%$ compared with the previous strategy without the use of rbST, but the C footprint decreased an additional $7 \%$ (Table 3, column 3 vs. column 2). Compared with the base farm, this combination of management changes increased the net GHG emission by $8 \%$ and reduced the C footprint by $15 \%$ (Table 3, column 3 vs. column 1).

For the next management option, the base farm was modified to maximize the use of forage in all animal diets (Rotz et al., 1999). With more fiber in diets, the animals produced more $\mathrm{CH}_{4}$ (Table 3 , column 4 vs. column 1). Excreted VS were also greater, creating a small increase in emissions from the manure storage. Harvesting of the additional forage required more machinery operations and fuel compared with the grain feed replaced, which increased combustion and secondary emissions. This led to an $18 \%$ increase in net GHG emission and $\mathrm{C}$ footprint.

The type of forage fed can also affect GHG emissions and $\mathrm{C}$ footprint. To illustrate this effect, the forage fed to the herd was changed to $75 \%$ corn silage and $25 \%$ alfalfa silage (Table 3, column 5). The change in fiber and starch contents in diets reduced animal and manure storage emissions of $\mathrm{CH}_{4}$ and $\mathrm{CO}_{2}$. Feed $\mathrm{N}$ was also used more efficiently, which provided a small decrease in excreted manure $\mathrm{N}$ and the resulting production of $\mathrm{N}_{2} \mathrm{O}$ from cropland. Corn silage production required less machinery and fuel compared with alfalfa, which 
Table 3. Selected management effects on the greenhouse gas (GHG) emissions and carbon footprint of a simulated representative 100-cow dairy farm in Pennsylvania

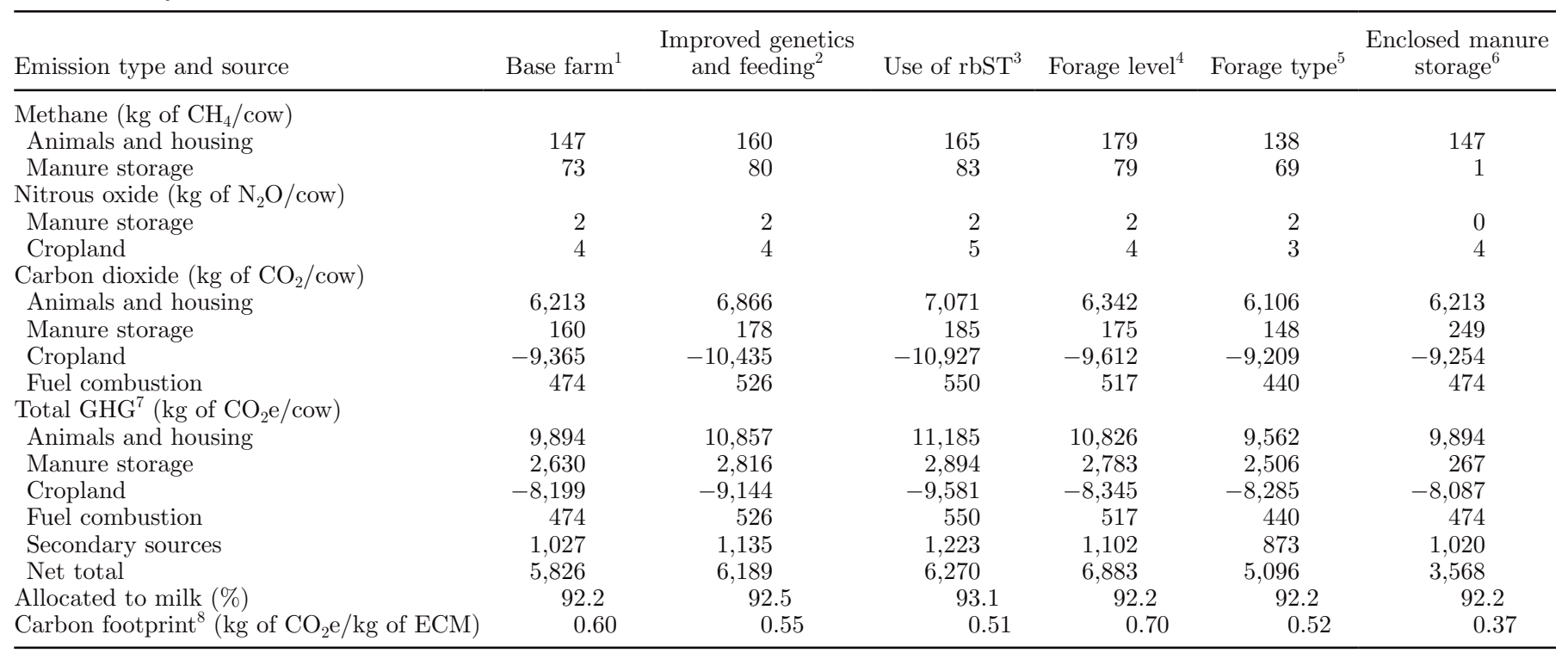

${ }^{1} 100$ moderate-sized Holstein cows plus replacement heifers housed in free stall barns. Annual milk production is $9,000 \mathrm{~kg} / \mathrm{cow}$. Total mixed rations are fed using high-grain diets (about $45 \%$ forage for all lactating groups), with $50 \%$ of the forage from corn silage, $35 \%$ alfalfa silage, and $15 \%$ hay. Manure is stored and spread in the spring and fall.

${ }^{2}$ Annual milk production is increased to $10,400 \mathrm{~kg} / \mathrm{cow}$ through improved genetics (large Holstein animals) and feeding management (higher milk production limited by feed quality).

${ }^{3}$ Annual milk production is increased to $11,400 \mathrm{~kg} / \mathrm{cow}$ through the use of recombinant bST along with the improved genetics and feeding management of scenario 2 (footnote 2 ).

${ }^{4}$ Same as scenario 1 (footnote 1) except all animal groups are fed maximum-forage diets (about 48, 60, and $70 \%$ forage for early, mid, and late lactation groups, respectively; Rotz et al., 1999).

${ }^{5}$ Same as scenario 1 (footnote 1) except corn silage production and use is increased to $75 \%$ of the forage, with the remainder from alfalfa silage and hay.

${ }^{6}$ Same as scenario 1 (footnote 1) except the manure storage tank is enclosed and the biogas generated is burned to convert the escaping $\mathrm{CH}_{4}$ to $\mathrm{CO}_{2}$.

${ }^{7} \mathrm{CO}_{2}$ equivalents for methane and nitrous oxide are 25 and 298 , respectively.

${ }^{8} \mathrm{CO}_{2} \mathrm{e}=\mathrm{CO}_{2}$ equivalent. ECM = energy corrected milk with $3.5 \%$ fat and $3.1 \%$ protein concentrations.

reduced emissions from fuel combustion and secondary sources. The net result was a $13 \%$ reduction in net GHG emission and C footprint (Table 3, column 5 vs. column 1).

As a final management option, an enclosed manure storage was used with a flare to burn the escaping biogas. This management change almost eliminated $\mathrm{CH}_{4}$ emission from the storage, but $\mathrm{CO}_{2}$ emission increased. With the enclosed storage, a crust would not form, which eliminated $\mathrm{N}_{2} \mathrm{O}$ formation and emission from the storage. The net result of this change was a $39 \%$ reduction in the net GHG emission and C footprint (Table 3, column 6 vs. column 1).

\section{Carbon Sequestration}

Although $\mathrm{C}$ sequestration is not directly included in this model, it is a factor that can have a major effect on C footprint during transition periods following major changes in cropping practices. Carbon sequestration refers to the transfer and long-term storage of atmospheric $\mathrm{CO}_{2}$ into stable $\mathrm{C}$ pools; that is, photosynthetically assimilated $\mathrm{C}$ in crop residue and manure is stored in soil organic matter (Bruce et al., 1999; Lal, 2008). The transformation of undisturbed soil ecosystems to cropland leads to a 20 to $50 \%$ loss of soil OM, creating a lower equilibrium level. Changes that lead to an increase in the amount of $\mathrm{C}$ entering the soil or a reduced rate of soil $\mathrm{C}$ decomposition can lead to increases in $\mathrm{C}$ storage. A summary of data from across North America indicates that conversion of tilled cropland to perennial grassland increases annual $\mathrm{C}$ sequestration by 0.3 to 1.0 tonnes of $\mathrm{C} / \mathrm{ha}$ depending upon soil and climate conditions (Franzluebbers and Follett, 2005). From the same summary, conversion of cropland from conventional tillage to no-tillage practices may increase annual sequestration by up to 0.5 tonnes of $\mathrm{C} / \mathrm{ha}$. Most of the sequestration occurs within 20 to $50 \mathrm{yr}$ following a 
change in production practice where the rate decreases with time as the ecosystem approaches a new equilibrium (Paustian et al. 1997; Bruce et al. 1999).

To illustrate the effect of sequestration on the $\mathrm{C}$ footprint, the effect of transitioning the 60 cow farm with confinement feeding of rotated crops to that including permanent pasture (Table 2, columns 1 and 2) can be estimated. Based upon a typical range in sequestration of 0.5 to 1.0 tonnes of $\mathrm{C} /$ ha per year for this type of transition (Franzluebbers and Follett, 2005) and a pasture yield of 6.5 tonnes of $\mathrm{DM} /$ ha, the reduction in the $\mathrm{C}$ footprint of this farm is 0.07 to $0.15 \mathrm{~kg}$ of $\mathrm{CO}_{2} / \mathrm{kg}$ of ECM produced. Thus, during the transition period, the footprint can be reduced by 10 to $22 \%$ to a value of 0.56 to $0.48 \mathrm{~kg}$ of $\mathrm{CO}_{2} / \mathrm{kg}$ of ECM. During this transition period of up to $50 \mathrm{yr}$, the $\mathrm{C}$ footprint would gradually increase to that listed in Table 2 (column 2).

\section{MODEL EVALUATION}

Validation of this type of model is not possible because any method of determining a $\mathrm{C}$ footprint is just an estimation. Model evaluation, though, is always important to ensure that reasonable values are predicted. Three forms of evaluation were conducted: a verification of individual model components, a comparison with previous studies of the $\mathrm{C}$ footprint of dairy production systems, and a sensitivity analysis.

\section{Verification of Model Components}

Relationships and factors used in individual components of the model to predict important emission sources have been evaluated through comparisons with measured data and other model predictions (Chianese et al., 2009b,c,d). These previous evaluations support that the component models used in the life cycle assessment of the full production system predict emissions similar to those found in previous studies.

\section{Comparison with Published Carbon Footprints}

Over the past $10 \mathrm{yr}$, several studies have determined $\mathrm{C}$ footprints for dairy production systems. To test the predictive ability of our model, 7 studies were selected that were done for temperate regions of the United States, Canada, and northern Europe (Table 4). These systems represented a range of production strategies, including grazing and confinement feeding systems, and a range of milk production levels. The studies also used different methods for allocating emissions between milk and the animal coproduct and different assumptions on the inclusion of $\mathrm{CO}_{2}$ emissions and the number and type of secondary sources (Table 4). Some studies

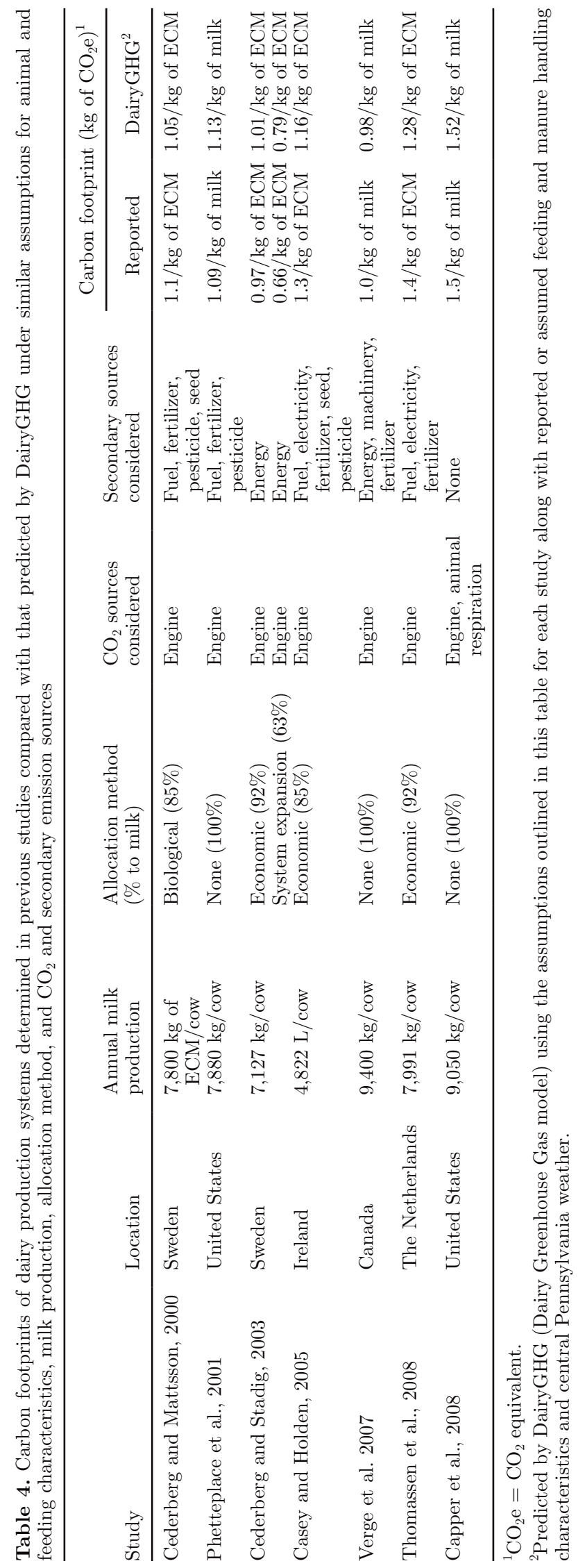


included comparisons with alternative systems such as organic production. In those cases, only the conventional system was included. Reported $\mathrm{C}$ footprints ranged from about 1.0 to $1.5 \mathrm{~kg}$ of $\mathrm{CO}_{2} / \mathrm{kg}$ of milk or ECM. An exception was when system expansion was used by Cederberg and Stadig (2003) to allocate between milk and animal coproducts. In this case, the footprint was reduced to $0.66 \mathrm{~kg}$ of $\mathrm{CO}_{2} / \mathrm{kg}$ of ECM.

DairyGHG was used to predict $\mathrm{C}$ footprints for the production systems represented in each of these studies using the same assumptions for annual herd milk production, allocation method, and $\mathrm{CO}_{2}$ and secondary emission sources. Many specific characteristics of the production systems were not documented, so assumptions on feeding and manure handling strategies were made based upon limited reported data and what would be expected in the given region of the study. Normally, these assumptions had relatively small effects on the predicted C footprint. All production systems were simulated using central Pennsylvania weather.

Reported footprints are compared with those predicted by DairyGHG in the last 2 columns of Table 4 . In most cases, predicted values were within $10 \%$ of those reported. Over the 7 studies, the correlation between predicted and reported values was 0.95 . The largest difference occurred when system expansion was used as the allocation method where DairyGHG predicted a footprint $20 \%$ greater than that determined by Cederberg and Stadig (2003). Considering the assumptions made to represent these various systems, this comparison supports that DairyGHG can represent these previous studies when similar assumptions are made on milk production, allocation method, and the sources of $\mathrm{CO}_{2}$ and secondary emissions.

DairyGHG includes components that expand the analyses of the previous studies (Figure 1). The major difference is that a full $\mathrm{C}$ balance of the production system can be included, which considers all important sinks and sources of $\mathrm{CO}_{2}$. This provides a more complete assessment of the cradle-to-farm gate $\mathrm{C}$ footprint. Carbon dioxide is assimilated in the feed produced that transforms to the $\mathrm{C}$ in milk and animals leaving the farm gate. A portion of this assimilated $\mathrm{C}$ in feed also is used to create the $\mathrm{CH}_{4}$ produced through enteric fermentation. As illustrated above, including the assimilated $\mathrm{CO}_{2}$ in feed along with additional $\mathrm{CO}_{2}$ emission sources creates a substantial reduction in the $\mathrm{C}$ footprint. This inclusion provides a more complete representation of the $\mathrm{C}$ footprint of the dairy production system. Ignoring the assimilation of $\mathrm{CO}_{2}$ essentially moves more of the total cradle-to-grave $\mathrm{C}$ footprint of milk from the consumer to the producer placing a greater burden upon the producer.

\section{Sensitivity Analysis}

The predicted $\mathrm{C}$ footprint is affected by the relationships and parameters used to predict each individual emission source. To further evaluate the relative importance of individual components, a sensitivity analysis was done to quantify how changes in each affected the overall footprint. For this purpose, a sensitivity index was defined as the percentage change in the carbon footprint for a $10 \%$ change in the given emission source divided by $10 \%$. Therefore, an index of 1 or greater indicates a high sensitivity where a change in the component source causes an equal or greater change in the footprint. A low value near 0 indicates a relatively low sensitivity where the change has little effect on the overall footprint.

The production system used will have some effect on the sensitivity of individual emission sources. For example, if long-term manure storage is not used, relationships used to predict this emission source will have no effect on the footprint of the system. Other factors such as feeding strategy will have more subtle effects. To obtain a general comparison of all emission sources, the base 100 cow farm of Table 3 (column 1) was used as representative of the most common production practices. In the cases where strategies such as the bedded pack barn were not used on this farm, the 60 cow farm of Table 2 (column 1) was used.

The emission source with the greatest effect on the overall $\mathrm{C}$ footprint was that of $\mathrm{CH}_{4}$ production by enteric fermentation in the animals (Figure 2). For this component, a sensitivity index of about 0.6 was found, which indicates that the $\mathrm{C}$ footprint is not highly sensitive even to this component. A 10\% error or change in the predicted emission from enteric fermentation creates a $6 \%$ change in the overall $\mathrm{C}$ footprint. This particular component is among the most thoroughly measured and modeled of all GHG emission sources from dairy farms (Chianese et al., 2009a,b). Therefore, error in predicting this component should be relatively small.

Component sources with a more moderate effect on the predicted $\mathrm{C}$ footprint included $\mathrm{CH}_{4}$ emissions from bedded pack and slurry manure storages and $\mathrm{N}_{2} \mathrm{O}$ emissions from slurry manure storages and cropland. Sensitivity indexes for each of these components were between 0.1 and 0.3. All other emission sources, including all secondary sources, had relatively low effects on the overall footprint, with indexes of 0.1 or less (Figure $2)$.

This sensitivity analysis further supports that the predicted $\mathrm{C}$ footprint for dairy production systems is robust. Model improvements for more accurate predic- 


\section{Methane}

Animals

Free stall barn floor

Tie stall \& bedded pack

Slurry manure storage

Field applied manure

Nitrous oxide

Bedded pack

Slurry manure storage

Cropland

\section{Carbon Dioxide}

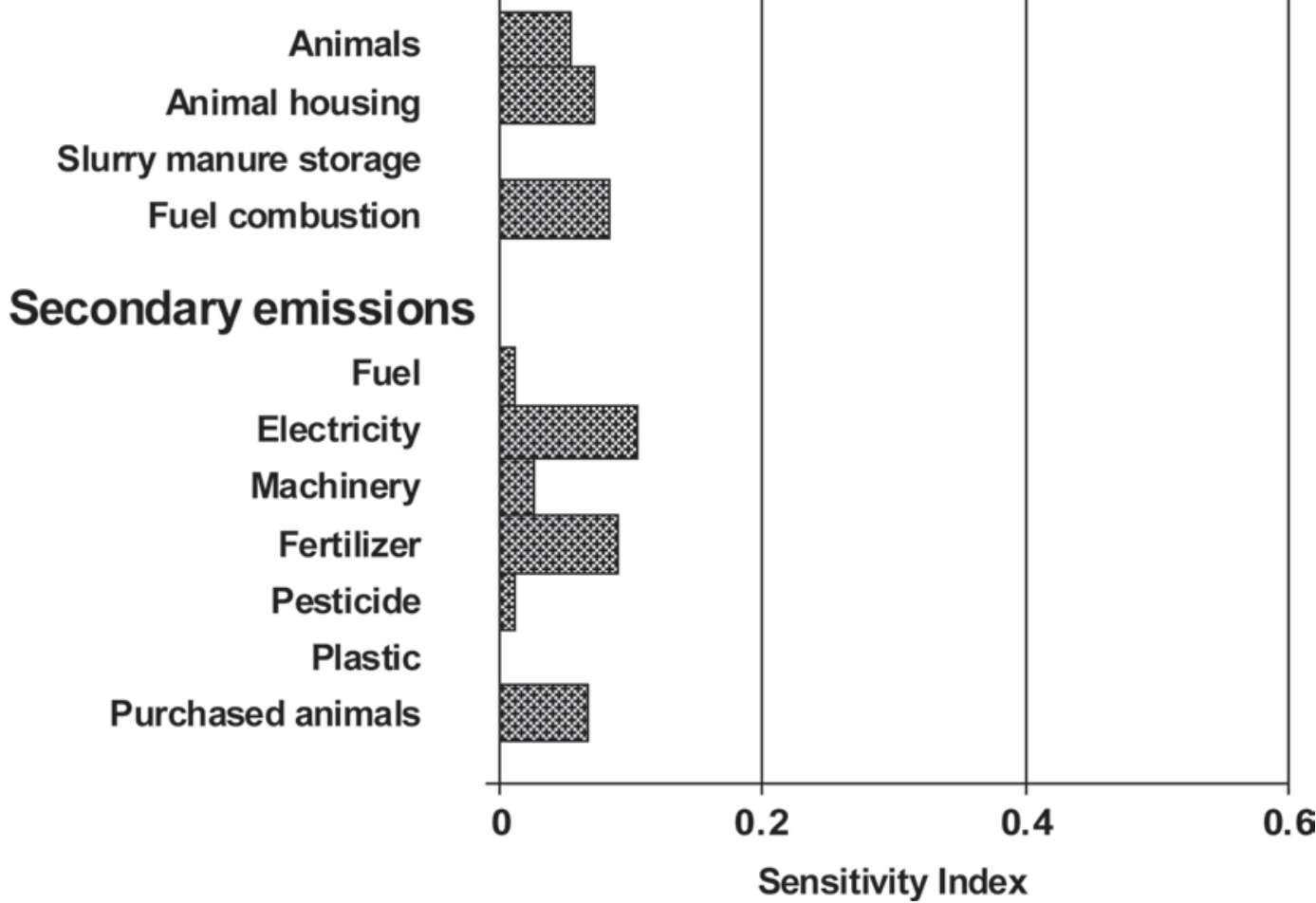

Figure 2. Sensitivity of the carbon footprint to changes in predicted emissions from each source in the dairy production system. The sensitivity index is the percentage change in the carbon footprint for a $10 \%$ change in the given emission source divided by $10 \%$.

tion of individual component emission sources would not have a major effect on predicted footprints.

This sensitivity analysis also indicates the system components where changes can have the greatest effect on reducing the $\mathrm{C}$ footprint. The component with the greatest potential is enteric fermentation. As illustrated in Table 3, diet changes are one means of obtaining minor reductions of this source of $\mathrm{CH}_{4}$. Feasible strate- gies for greatly reducing this source while maintaining milk production and animal health are not yet known. The next most important, and perhaps most feasible, strategy is elimination or improvement of manure storage. Manure storage is a source of $\mathrm{CH}_{4}, \mathrm{~N}_{2} \mathrm{O}$, and $\mathrm{CO}_{2}$ emissions. Other steps that can have some effect are the reduction in use of fuel, electricity, and inorganic fertilizer. 


\section{CONCLUSIONS}

Relationships for predicting all of the important primary and secondary GHG emissions in dairy production were integrated in the Dairy Greenhouse Gas model (DairyGHG) to provide a software tool for estimating the net GHG emission and C footprint of production systems.

The cradle-to-farm gate $\mathrm{C}$ footprint of commonly used production practices was found to vary from 0.37 to $0.69 \mathrm{~kg}$ of $\mathrm{CO}_{2} / \mathrm{kg}$ of ECM produced, depending upon milk production level and the feeding and manure handling strategies used in the production system.

In a comparison with previous studies, DairyGHG predicted $\mathrm{C}$ footprints similar to those reported when similar assumptions were used for feeding strategy, milk production, allocation between milk and animal coproducts, and sources of $\mathrm{CO}_{2}$ and secondary emissions.

Model-predicted $\mathrm{C}$ footprints were most sensitive to the relationships used to predict the $\mathrm{CH}_{4}$ from enteric fermentation, moderately sensitive to those for $\mathrm{CH}_{4}$, $\mathrm{N}_{2} \mathrm{O}$, and $\mathrm{CO}_{2}$ emissions from long-term manure storage, and mildly sensitive to those for the amount of fuel, electricity, and inorganic fertilizer used on the farm.

\section{REFERENCES}

AMPE. 2008. Eco-Profiles of the European Plastics Industry. Association of Polymer Manufacturers in Europe, Brussels, Belgium. http:// lca.plasticseurope.org/main2.htm Accessed March 8, 2008.

Bailey, J., and D. Ollis. 1986. Biochemical Engineering Fundamentals. 2nd ed. McGraw-Hill, New York, NY.

Bath, M., B. English, A. Turhollow, and H. Nyangito. 1994. Energy in Synthetic Fertilizers and Pesticides: Revisited. Oakridge National Laboratory, Oak Ridge, TN. http://www.osti.gov/energycitations/ servlets/purl/10120269-p6yhLc/webviewable/10120269. PDF Accessed July 9, 2008.

Borjesson, P. 1996. Energy analysis of biomass production and transportation. Biomass Bioenergy 11:305-318.

Bowers, W. 1992. Agricultural field equipment. Pages 117-129 in Energy in Farm Production. R. Fluck, ed. Elsevier, Amsterdam, the Netherlands.

Bruce, J. P., M. Frome, E. Haites, H. Janzen, R. Lal, and K. Paustian. 1999. Carbon sequestration in soils. J. Soil Water Conserv. $54: 382-389$.

Capper, J. L., E. Castaneda-Gutierrez, R. A. Cady, and D. E. Bauman. 2008. The environmental impact of recombinant bovine somatotropin (rbST) use in dairy production. Proc. Natl. Acad. Sci. USA 105:9668-9673.

Casey, J. W., and N. M. Holden. 2005. Analysis of greenhouse gas emissions from the Irish milk production system. Agric. Syst. 86:97-114.

Cederberg, C., and B. Mattsson. 2000. Life cycle assessment of milk production-A comparison of conventional and organic farming. J. Clean. Prod. 8:49-60.

Cederberg, C., and M. Stadig. 2003. System expansion and allocation in life cycle assessment of milk and beef production. Int. J. Life Cycle Assess. 8:350-356.

Chianese, D. S., C. A. Rotz, and T. L. Richard. 2009a. Wholefarm greenhouse gas emissions: A review with application to a Pennsylvania dairy farm. Appl. Eng. Agric. 25:431-442.

Chianese, D. S., C. A. Rotz, and T. L. Richard. 2009b. Simulation of carbon dioxide emissions from dairy farms to assess greenhouse gas reduction strategies. Trans. ASABE 52:1301-1312.
Chianese, D. S., C. A. Rotz, and T. L. Richard. 2009c. Simulation of methane emissions from dairy farms to assess greenhouse gas reduction strategies. Trans. ASABE 52:1313-1323.

Chianese, D. S., C. A. Rotz, and T. L. Richard. 2009d. Simulation of nitrous oxide emissions from dairy farms to assess greenhouse gas reduction strategies. Trans. ASABE 52:1325-1335.

Dalgaard, T., N. Halberg, and J. Porter. 2001. A model for fossil energy use in Danish agriculture used to compare organic and conventional farming. Agric. Ecosyst. Environ. 87:51-65.

Doering, O. 1980. Accounting for energy in farm machinery and buildings. Pages 9-21 in Handbook of Energy Utilization in Agriculture. D. Pimentel, ed. CRC Press Inc., Boca Raton, FL.

Energy Information Administration (EIA). 2006. Emissions of Greenhouse Gases in the United States 2005. DOE/EIA-0573 (2004). U.S. Department of Energy, Washington, DC. http://www. eia.doe.gov/oiaf/1605/ggrpt/ Accessed November 12, 2007.

EPA. 1999. U.S. Methane Emissions 1990-2020: Inventories, Projections, and Opportunities for Reductions. EPA 430-R-99-013. U.S. Environmental Protection Agency, Washington, DC. http:// www.epa.gov/ghginfo Accessed November 23, 2007.

EPA. 2008. Inventory of U.S. Greenhouse Gas Emissions and Sinks: 1990-2006. EPA 430-R-08-005. U.S. Environmental Protection Agency, Washington, DC. http://www.epa.gov/climatechange/ emissions/downloads/08_Annex_6.pdf Accessed July 9, 2008.

Farrell, A., R. Plevin, B. Turner, A. Jones, M. O'Hare, and D. Kammen. 2006. Ethanol can contribute to energy and environmental goals. Science 311:506-508. http://www.sciencemag.org/cgi/content/ full/311/5760/506/DC1 Accessed July 9, 2008.

Fluck, R. 1992. Energy analysis for agricultural systems. Pages 45-52 in Energy in Farm Production. R. Fluck, ed. Elsevier, Amsterdam, the Netherlands.

FAO. 2006. Livestock's Long Shadow. Food and Agriculture Organization, Rome, Italy.

Fox, D. G., L. O. Tedeschi, T. P. Tylutki, J. B. Russell, M. E. Van Amburgh, L. E. Chase, A. N. Pell, and T. R. Overton. 2004. The Cornell net carbohydrate and protein system model for evaluating herd nutrition and nutrient excretion. Anim. Feed Sci. Technol. 112:29-78.

Franzluebbers, A., and R. Follett. 2005. Greenhouse gas contributions and mitigation potential in agricultural regions of North America: Introduction. Soil Tillage Res. 83:1-8.

Garrain, D., P. Martinez, and R. Vidal. 2007. LCA of thermoplastics recycling. In Proc. 3rd International Conference of Life Cycle Assessment. Zurich, Austria. http://www.lcm2007.org/paper/168. pdf Accessed July 9, 2008.

Graboski, M. 2002. Fossil Energy Use in the Manufacture of Corn Ethanol. National Corn Growers Association, Chesterfield, MO. http://www.ncga.com/ethanol/pdfs/energy_balance_report_ final_R1.PDF Accessed July 9, 2008.

Griffin, T. S., S. He, and C. W. Honeycutt. 2003. Manure composition affects net transformation of nitrogen from dairy manures. Plant Soil 273:29-38.

IPCC. 2001. Climate Change 2001: The Scientific Basis. Contribution of Working Group I to the Third Assessment Report of the Intergovernmental Panel on Climate Change. Cambridge University Press, Cambridge, UK

IPCC. 2006. Guidelines for National Greenhouse Inventories. Vol. 4 Agriculture, Forestry and other Land Use. http://www.ipcc-nggip. iges.or.jp/public/2006gl/vol4.html Accessed November 26, 2008.

IPCC. 2007. Changes in atmospheric constituents and in radiative forcing. Chapter 2 in Climate Change 2007: The Physical Science Basis. Contribution of Working Group I to the Fourth Assessment Report of the Intergovernmental Panel on Climate Change. http:// www.ipcc.ch/pdf/assessment-report/ar4/wg1/ar4-wg1-chapter2. pdf Accessed November 28, 2008.

Jarvis, S. C., R. D. Lovell, and R. Panayides. 1995. Patterns of methane emission from excreta of grazing animals. Soil Biol. Biochem. 27:1581-1588.

Kirchgessner, M., W. Windisch, H. L. Müller, and M. Kreuzer. 1991. Release of methane and of carbon dioxide by dairy cattle. Agribiol. Res. 44:91-102. 
Kitzes, J., M. Wackernagel, J. Loh, A. Peller, S. Goldfinger, D. Cheng, and K. Tea. 2008. Shrink and share: Humanity's present and future ecological footprint. Phil. Trans. Biol. Sci. 363:467-475.

Lal, R. 2008. Carbon sequestration. Phil. Trans. Biol. Sci. 363:815830.

Lee, J., H. Cho, J. Sung, S. Lee, and M. Shin. 2000. Life cycle assessment of tractors (Korean example). LCA Case Studies. Int. J. Life Cycle Assess. 5:205-208.

Ludington, D., and E. L. Johnson. 2003. Dairy Farm Energy Audit Summary. FlexTech Services, New York State Energy Research and Development Authority, Albany, NY. http://www.nyserda. org/publications/dairyfarmenergysummary.pdf Accessed May 18, 2009

Mills, J. A. N., E. Kebreab, C. M. Yates, L. A. Crompton, S. B. Cammell, M. S. Dhanoa, R. E. Agnew, and J. France. 2003 Alternative approaches to predicting methane emissions from dairy cows. J. Anim. Sci. 81:3141-3150.

Monteny, G. J., C. M. Groenestein, and M. A. Hilhorst. 2001. Interactions and coupling between emissions of methane and nitrous oxide from animal husbandry. Nutr. Cycl. Agroecosyst. 60:123-132.

Nagy, C. 1999. Energy Coefficients for Agriculture Inputs in Western Canada. Canadian Agricultural Energy End-Use Data Analysis Centre, Saskatoon, Saskatchewan, Canada. http://www.csale. usask.ca/PDFDocuments/energyCoefficientsAg.pdf Accessed July 9,2008

NRC. 2003. Air Emissions from Animal Feeding Operations: Current Knowledge, Future Needs. Natl. Acad. Sci., Washington, DC

Olesen, J. E., K. Schelde, A. Weiske, M. R. Weisbjerg, W. A. H. Asman, and J. Djurhuus. 2006. Modelling greenhouse gas emissions from European conventional and organic dairy farms. Agric. Ecosyst. Environ. 112:207-220.

Patzek, T. 2004. Thermodynamics of the corn-ethanol biofuel cycle. Crit. Rev. Plant Sci. 23:519-567.

Paustian, K., O. Andrén, H. Janzen, R. Lal, P. Smith, G. Tian, H. Tiessen, M. Van Noordwijk, and P. Woomer. 1997. Agricultural soils as a sink to mitigate $\mathrm{CO}_{2}$ emissions. Soil Use Manage. $13: 230-244$.

Pennsylvania Agricultural Statistics Service (PASS). 2008. Pennsylvania Agricultural Statistics, Prices Received. http://www.nass.usda. gov/QuickStats/index2.jsp Accessed January 10, 2009.

Phetteplace, H. W., D. E. Johnson, and A. F. Seidl. 2001. Greenhouse gas emissions from simulated beef and dairy livestock systems in the United States. Nutr. Cycl. Agroecosyst. 60:99-102.

Pimentel, D. 1980. Energy inputs for the production, formulation, packaging and transport of various pesticides. Pages $45-48$ in Handbook of Energy Utilization in Agriculture. D. Pimentel, ed. CRC Press Inc., Boca Raton, FL.

Rotz, C. A. 2004. Management to reduce nitrogen losses in animal production. J. Anim. Sci. 82(E-Suppl.):E119-E137.

Rotz, C. A., M. S. Corson, D. S. Chianese, and C. U. Coiner. 2009. Integrated Farm System Model: Reference Manual. Pasture Systems and Watershed Management Research Unit, USDA Agricultural Research Service, University Park, PA. http://ars.usda.gov/
SP2UserFiles/Place/19020000/ifsmreference.pdf Accessed August $31,2008$.

Rotz, C. A., D. R. Mertens, D. R. Buckmaster, M. S. Allen, and J. H. Harrison. 1999. A dairy herd model for use in whole farm simulations. J. Dairy Sci. 82:2826-2840.

Savoie, P., and J. C. Jofriet. 2003. Silage storage. Pages 405-467 in Silage Science and Technology. D. R. Buxton, R. E. Muck, and J. H. Harrison, ed. Agronomy monograph 42. American Society of Agronomy, Madison, WI.

Schmer, M., K. Vogel, R. Mitchell, and R. Perrin. 2008. Net energy of cellulosic ethanol from switchgrass. Proc. Natl. Acad. Sci. Unit. Sci. Am. 105:464-469.

Schroll, H. 1994. Energy flow and ecological sustainability in Danish agriculture. Agric. Ecosyst. Environ. 51:301-310.

Sherlock, R. R., S. G. Sommer, R. Z. Khan, C. W. Wood, E. A Guertal, J. R. Freney, C. O. Dawson, and K. C. Cameron. 2002. Emission of ammonia, methane and nitrous oxide from pig slurry applied to a pasture in New Zealand. J. Environ. Qual. 31:14911501

Sommer, S. G., S. O. Petersen, and H. B. Møller. 2004. Algorithms for calculating methane and nitrous oxide emissions from manure management. Nutr. Cycl. Agroecosyst. 69:143-154.

Sommer, S. G., R. R. Sherlock, and R. Z. Khan. 1996. Nitrous oxide and methane emissions from pig slurry amended soils. Soil Biol. Biochem. 28:1541-1544.

Thomassen, M. A., K. J. van Calker, M. C. J. Smits, G. L. Iepema and I. J. M. de Boer. 2008. Life cycle assessment of conventional and organic milk production in the Netherlands. Agric. Syst. 96:95-107.

USDA. 2005. USDA National Nutrient Database. Release 18. http:// www.nal.usda.gov/fnic/foodcomp/Data/SR18/reports/sr18page. htm Accessed October 30, 2009.

Verge, X. P. C., J. A. Dyer, R. L. Desjardins, and D. Worth. 2007. Greenhouse gas emissions from the Canadian dairy industry in 2001. Agric. Syst. 94:683-693.

Wang, M. 2007. GREET. Version 1.8a. Argonne National Laboratory Argonne, IL. http://www.transportation.anl.gov/software/ GREET/ Accessed January, 2008.

West, T., and G. Marland. 2002. A synthesis of carbon sequestration, carbon emissions, and net carbon flux in agriculture: Comparing tillage practices in the United States. Agric. Ecosyst. Environ. 91:217-232.

Wilkerson, V. A., D. P. Casper, and D. R. Mertens. 1995. The prediction of methane production of Holstein cows by several equations. J. Dairy Sci. 78:2402-2414.

Wu, M., M. Wang, and H. Huo. 2006. Fuel-Cycle Assessment of Selected Bioethanol Production Pathways in the United States. ANL/ ESD/06-7. Center for Transportation Research, Energy Systems Division, Argonne National Laboratory, Argonne, IL. http://www. transportation.anl.gov/pdfs/TA/377.pdf Accessed July 9, 2008.

Yamulki, S., S. C. Jarvis, and P. Owen. 1999. Methane emission and uptake from soils as influenced by excreta deposition from grazing animals. J. Environ. Qual. 28:676-682. 